\title{
EKSTRAKSI BAKTERI ASAL EKTOMIKORIZA SEBAGAI AGEN ANTAGONIS PENYAKIT TANAMAN FUSARIUM
}

\section{(Extraction of Ektomycorrizae-Based Bacteria as an Antagonist Agent of Fusarium Disease of Plant)}

\author{
IG. SEPTRIALDY SALEDA MALIN ${ }^{1}$, NUNANG LAMEK MAY ${ }^{1 凶}$, MUTAKIM $^{1}$ \\ Jurusan Kehutanan, Fakultas Kehutanan Universitas Papua Manokwari, Papua Barat, 98314. \\ Tlp/Fax: +62986211065. \\ Penulis Korespondensi: Email: nunangmay@gmail.com \\ Diterima: 20 Feb 2020| Disetujui:15 Mar 2020
}

\begin{abstract}
Abstrak. Ketidakseimbangan interaksi antara tanaman dan komponen biotik dan abiotik merupakan salah satu sumber penyakit. Tujuan dari penelitian ini adalah untuk mendapatkan jumlah bakteri dari ekstraksi Scleroderma citrinum yang menggambarkan morfologi bakteri dan mengamati respon bakteri potensial dalam melawan agen antagonis penyakit Fusarium sp. Hasil penelitian mendapatkan sebanyak 7 jenis bakteri $S$. citrinum ectomycorrhiza yang mempunyai kemampuan menangkal berbagai penyakit dari Fusarium sp. Ke 7 jenis bakteri S. citrinum memiliki tampilan morfologi yang berbeda. Morfologi bakteri dapat digambarkan yang didasarkan pada bentuk, sudut, warna, dan permukaan. Hasil tes antagonis dari isolasi bakteri Scl 7 merupakan pendugaan dan mempunyai potensi untuk menghalau Fusarium sp., pathogen, yang mana ini dapat dilihat dari tingginya persentase inhibisi yakni $41,11 \%$. Dari penelitian ini, teramati bahwa tidak ada exploitasi nyata oleh bakteri $S$. citrinum terhadap Fusarium sp. Sehingga dengan demikian, bakteri S. citrinum diduga memiliki karakteristik antibiosis dan adanya peran persaingan (pesaing nutrisi).
\end{abstract}

Kata kunci: ectomycorrhiza, S. citrinum, fusarium sp, antagonis, kontrol biologi

Abstract. Unbalanced interaction between plant and biotic or abiotic components is one of sources to accelerate the presence of disease. The purpose of this study was to obtain an amount of bacteria from Scleroderma citrinum extraction which was describing bacteria morphology, and observed a response of the potential bacteria $S$. citrinum as antagonists against the disease of Fusarium sp. The results obtained 7 species bacteria from S. citrinum ectomycorrhiza wich had ability to inhibition of different Fusarium sp., diseases. In addition, the 7 types of bacteria S. citrinum had different morphology. Bacterial morphology can be described based on their shapes, edges, colors, and surfaces. The result of antagonistic test of bacterial isolate Scl 7 was suspected and had the potential to inhibit Fusarium sp., pathogen, in which it can be seen from the highest percentage from percentage of inhibition of $41.11 \%$. From the study, it has been observed that no visible exploitation by bacteria $S$. citrinum as antagonist against Fusarium sp. Therefore, bacteria $S$. citrinum was suspected to contain antibiosis and competition (nutrient competitor) characteristic.

Keywords: ectomycorrhiza, S. citrinum, fusarium sp, antagonist, biological control 


\section{PENDAHULUAN}

Kawasan Taman Wisata Alam (TWA) Gunung Meja merupakan salah satu kawasan konservasi dengan fungsi hidrologis yang berperan sebagai catchment area, TWA Gunung Meja juga memenuhi kebutuhan air sebagian masyarakat kota Manokwari. Kawasan yang berada pada ketinggian antara 16-210 meter dpl, dengan topografi lapangan bervariasi dari datar hingga bergelombang ringan ke arah timur dan bergelombang berat dari timur ke arah barat dengan puncak tertinggi (Puncak Bonay) \pm 210 meter dpl, kawasan TWA Gunung Meja termasuk wilayah dengan tipe iklim A (Hutan hujan tropika basah).

Tipe iklim A ini dicirikan dengan tingginya curah hujan tahunan yang terjadi mencapai ratarata $2.084,20 \mathrm{~mm} /$ tahun atau $173,68 \mathrm{~mm} / \mathrm{bulan}$, dimana ratarata kelembaban udara pertahunnya adalah $83,52 \%$ dengan kelembaban maksimum $87 \%$ dan kelembaban minimum $80 \%$, dimana intensitas cahaya matahari mencapai 57,87 $\% /$ tahun, tempertur udaraminimum23,51 ${ }^{\circ} \mathrm{C}$ dan maksimum $31,87{ }^{\circ} \mathrm{C}$. Kawasan TWA Gunung Meja memiliki \pm 30 mata air berupa gua-gua dan mata air yang tersebar di dalam dan sekitar kawasan. Secara lithostratigarfi, kawasan ini termasuk dalam strata Formasi Manokwari (formasi befoor) yang terdiri dari batu gamping terumbu, sedikit biomikrit, kasidurit dan kalkarenit mengandung ganggang dan foraminitera.

TWA Gunung Meja didominasi oleh jenisjenis: Pometia coreacea, Pimelodendron amboinicum, Pometia pinnata, Palaquium amboinensis, Intsia bijuga, Koordersiodendron pinnatum, Antiaris toxycarya, Pterygota horsfieldia, Sterculia parkinsonii dan Spathiostemon javensis. TWA Gunung Meja juga merupakan habitat yang potensial bagi kehidupan satwa liar. Pada kawasan ini dapat dijumpai 15 jenis dari 6 famili mamalia, 35 jenis burung (aves) dari 20 famili, 20 jenis herpetofauna (7 kadal, 3 ampibia, 9 jenis ular dan 1 jenis kura-kura).

Semangun (2001), menyatakan interaksi antara tumbuhan hutan dan komponen lingkungan selalu terjadi pada tiap bentuk ekosistem hutan. Ketidakseimbangan interaksi antara tumbuhan dan unsur komponen lainnya termasuk komponen biotik atau abiotik adalah sebagai penyebab penyakit. Penyakit tumbuhan merupakan proses interaksi yang berjalan terus menerus, akibatnya juga proses fisiologis tumbuhan berubah hingga pertumbuhan dan perkembangannya mengarah ke arah yang tidak menguntungkan, atau bahkan sampai menyebabkan kematian, yang di mana komponen penyebabnya dikenal sebagai patogen.

Hadi (2001), mikroorganisme merupakan makhluk hidup yang sangat kecil sehingga hanya dapat dilihat menggunakan mikroskop. Adapun macammacam mikroorganisme yang meliputi bakteri, virus, dan jamur. Jenis mikroorganisme tertentu dapat menyebabkan kerusakan pada makanan dan juga beberapa di antaranya dapat menyebabkan keracunan pada makanan. Mikroorganisme ada juga yang menguntungkan dan dapat digunakan untuk mengubah karakteristik pada makanan dan untuk memperpanjang masa simpan produkproduk tertentu.

Hadi (2001) faktor penekan terhadap tumbuhan tidak bekerja secara sendiri-sendiri, baik serangga, fungi, nematoda, virus, mirkoplasma, serta manusia, dan hewan yang membuat luka pada batang pohon ataupun faktor fisik dan kimia, termasuk lingkungan. Faktor-faktor tersebut mampu mempengaruhi tumbuhan sehingga dapat menyebabkan tumbuhan hutan tertekan atau terganggu dalam pertumbuhan dan perkembangannya sehingga tumbuhan tersebut terserang penyakit. Adapaun tujuan dilakukan penelitian ini, adalah untuk mendapatkan jumlah bakteri dari hasil ekstraksi Scleroderma citrinum, mendeskripsikan 
morfologi bakteri asal $S$. citrinum, dan mengamati respons bakteri asal $S$. citrinum yang berpotensi sebagai antagonis terhadap penyakit Fusarium sp.

\section{METODE PENELITIAN}

Penelitian ini dilaksanakan pada Laboratorium Silvikultur Fakultas Kehutanan Universitas Papua selama 1 bulan yang dimulai dari bulan April sampai dengan Mei tahun 2018.

\section{Prosedur Penelitian}

Pengambilan Jamur di Lapangan

Pengambilan badan buah Ektomikoriza jenis Scleroderma citrinum di Taman Wisata Alam Gunung Meja Manokwari, di bawah tegakan Intsia bijuga dengan banyaknya jumlah badan buah ektomkoriza yang diambil adalah 4 badan buah.

\section{Pembuatan Media Tanam}

Media yang digunakan pada penelitian ini terdiri dari 2 media, yaitu media PDA (Potato Dextrose Agar) yang di gunakan untuk perbanyakan cendawan patogen Fusarium sp., dan uji antagonis, kemudian media NA (Natrient Agar) yang digunakan untuk mengisolasi bakteri hasil ekstraksi. Pembuatan dan komposisi media PDA dan juga NA diuraikan sebagai berikut: PDA (Potato Dextrose Agar)

Alat-alat yang digunakan dalam pembuatan media PDA antara lain aoutoclave, hot plate, timbangan analitik, gelas ukur, gelas piala, labu erlenmeyer, spatula dan pisau, sedangkan bahan-bahan yang digunakan yaitu kentang, agar-agar bening, gula, aquades, kapas, dan aluminium foil proses pembuatan media PDA diuaraikan sebagai berikut :

a. Kentang, gula dan agar-agar ditimbang menggunakan timbangan analitik sesuai kententuan yang telah ditentukan yaitu kentang sebanyak 200 gr, gula sebanyak 20 gr dan agar-agar sebanyak 15 gr.

b. Kentang dipotong berbentuk dadu atau ukuran lebih kecil.

c. Potongan kentang selanjutnya dimasukan kedalam gelas piala yang telah berisi aquades sebanyak $1000 \mathrm{ml}$, kemudian dimasak menggunakan hot plate hingga lunak untuk mendapatkan sari dari kentang tersebut.

d. Sari kentang selanjutnya dipanaskan lagi, kemudian gula dituangkan dan diaduk hingga larut selanjutnya agar-agar dituangkan dan aduk hingga benarbenar larut.

e. Selanjutnya larutan tersebut dituangkan ke dalam 2 buah labu erlenmeyer dengan takaran yang sama yaitu $500 \mathrm{ml}$.

f. Tutup rapat labu erlenmeyer dengan menggunakan kapas kemudian lapisi dengan aluminium foil.

g. Larutan media PDA tersebut selanjutnya disterilkan menggunakan aoutoclave dengan suhu $121{ }^{\circ} \mathrm{C}$ dan tekanan 1 atm selama 15 menit.

NA (Nutrient Agar)

Alat-alat yang digunakan dalam pembuatan media NA adalah autoclave, hot palte, timbangan analitik, gelas ukur, gelas piala, labu erlenmeyer, dan spatula. Bahan- bahan yang digunakan adalah nutrient agar, aquades, kapas dan aluminium foil. Proses pembuatan media NA diuraikan sebagai berikut :

a. Nutrient agar ditimbang sebanyak 20 gr menggunakan timbangan analitik dengan ketentuan yang sudah ditentuksn dan dilarutkan dalam $500 \mathrm{ml}$ aquades, setelah larut sempurna tambahkan aquades hingga tanda tera $(1000 \mathrm{ml})$.

b. Selanjutnya larutan tersebut dituangkan kedalam 2 buah labu erlenmeyer dengan volume masing-masing sebanyak $500 \mathrm{ml}$. 
c. Tutup rapat labu erlenmeyer dengan menggunakan kapas kemudian lapisi dengan aluminium foil.

d. Larutan media PDA tersebut selanjutnya disterilkan menggunakan aoutoclave dengan suhu $121{ }^{\circ} \mathrm{C}$ dan tekanan $1 \mathrm{~atm}$ selama 15 menit.

\section{Isolasi Bakteri}

Pada tahap ini metode yang digunakan ialah metode tuang. S. citrinum dicuci dibawah air mengalir dengan menggunakan sabun (sunlight), setelah di bersihkan kemudian ditiriskan. Sterilisasi jamur $S$. citrinum dilakukan di Laminar air flow cabinet dengan menyemprotkan alkohol $70 \%$ pada badan buah jamur, kemudian di cacah menggunakan scapel dan di masukan dalam botol yang sudah berisi air steril sebanyak $100 \mathrm{ml}$ untuk di ekstrak dan di kocok selama 5 menit. Selanjutnya ekstrak yang dihasilkan dibuat seri pengenceran hingga seri tingkat ke 4 dengan mengambil $10 \mathrm{ml}$ ekstrak dan di masukan ke dalam botol yang sudah berisi $100 \mathrm{ml}$ air steril. Masing-masing seri pengenceran diambil sebanyak $1 \mathrm{ml}$ kemudian diteteskan pada media NA dengan membuat 4 titik pada cawan petri dengan pengulangan sebanyak 3 kali. Selanjutnya diinkubasi pada suhu ruangan $25^{\circ} \mathrm{C}$ selama \pm 3 hari untuk mendapatkan koloni bakteri.

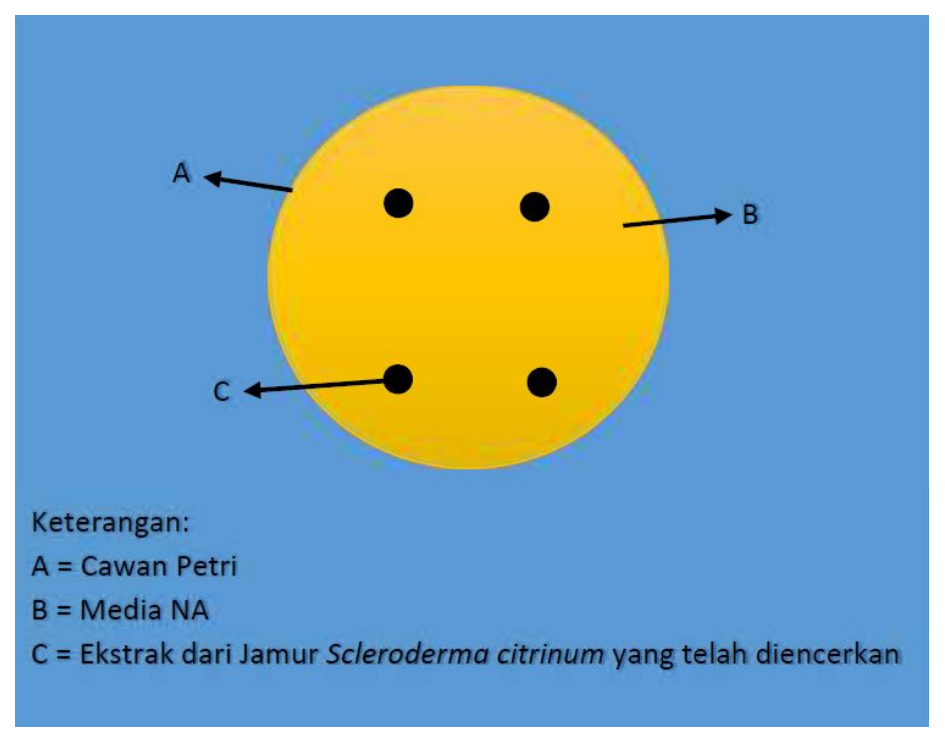

Gambar 1. Model pengenceran dari ekstrak jamur S. citrinum

\section{Perbanyakan Cendawan Patogen}

Patogen yang digunakan dalam penelitian ini adalah Fusarium sp. Perbanyakan biakan murni dilakukan secara aseptik pada Laminar air flow cabinet, dengan cara membuat lubang ukuran $0,6 \mathrm{~cm}$ menggunakan cop bor pada cawan petri yang telah terisi media PDA. Selanjutnya miselium cendawan patogen diambil dengan cop bor sesuai ukuran lubang yang telah dibuat. Miselium tersebut selanjutnya diinkubasi pada suhu ruangan $25^{\circ} \mathrm{C}$ selama \pm 3 hari. 


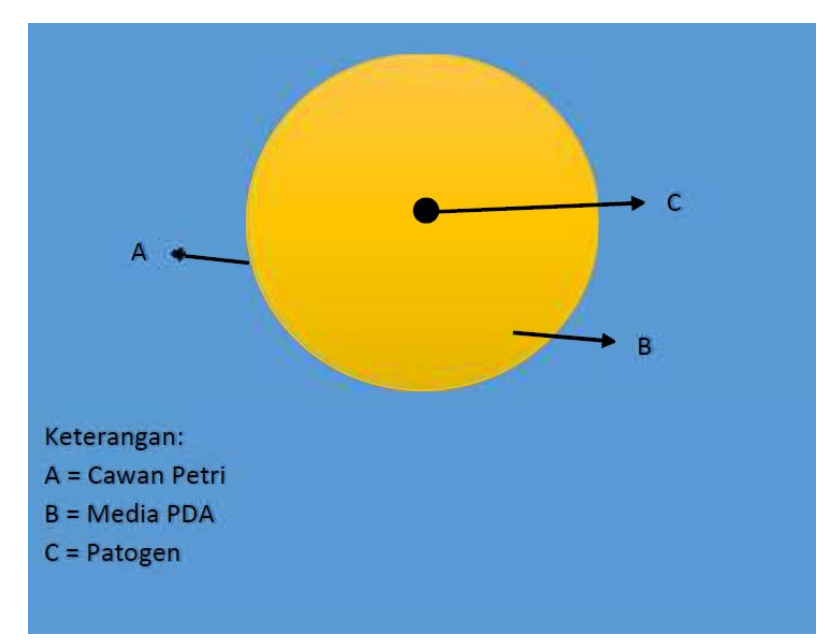

Gambar 2. Model perbanyakan patogen Fusarium sp.

\section{Pemurnian Bakteri}

Permurnian bakteri menggunakan metode gores dimana bakteri yang telah didapatkan dari jamur S. citrinum kemudian pembuatan biakan murni dari bakteri-bakteri tersebut dilakukan secara aseptik pada laminar air flow cabinet dengan menggoreskan bakteri menggunakan jarum ose pada media NA dalam cawan petri, selanjutnya bakteri tersebut diinkubasi pada suhu ruangan $25{ }^{\circ} \mathrm{C}$ selama \pm 3 hari.

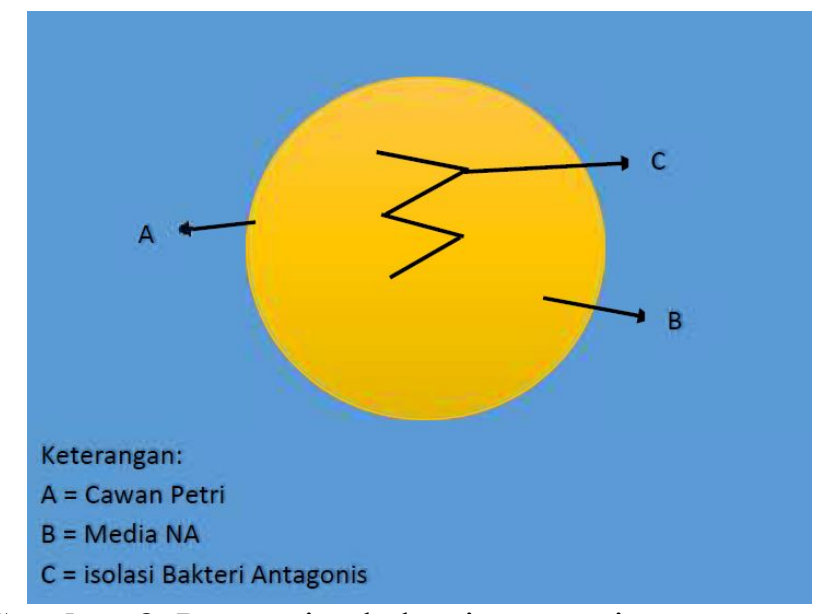

Gambar 3. Pemurnian bakteri antagonis

\section{Pengujian Bakteri dengan Penyakit \\ Tanaman (Uji Antagonis)}

Uji antagonis bakteri pada penyakit tanaman dilakukan secara in vitro, dilakukan untuk melihat respons dari bakteri asal jamur $S$. citrinum terhadap pertumbuhan cendawan penyakit tanaman. Pengujian dilakukan menggunakan metode Varese et al. (1996) dalam May (2011). Cendawan patogen ditumbuhkan pada cawan petri yang berukuran $9 \mathrm{~cm}$ yang berisi media PDA, kemudian di 
ambil koloni bakteri asal $S$. citrinum dan ditempatkan pada cawan petri pada jarak $1 \mathrm{~cm}$ dari bagian terluar dilingkari mengelilingi cendawan patogen. Kemudian cawan petri dieratkan dengan plastic wrap dan diinkubasi dalam keadaan gelap pada suhu $25^{\circ} \mathrm{C}$ dengan batas waktu pengamatan hingga penuhnya cendawan patogen pada kontrol media PDA.

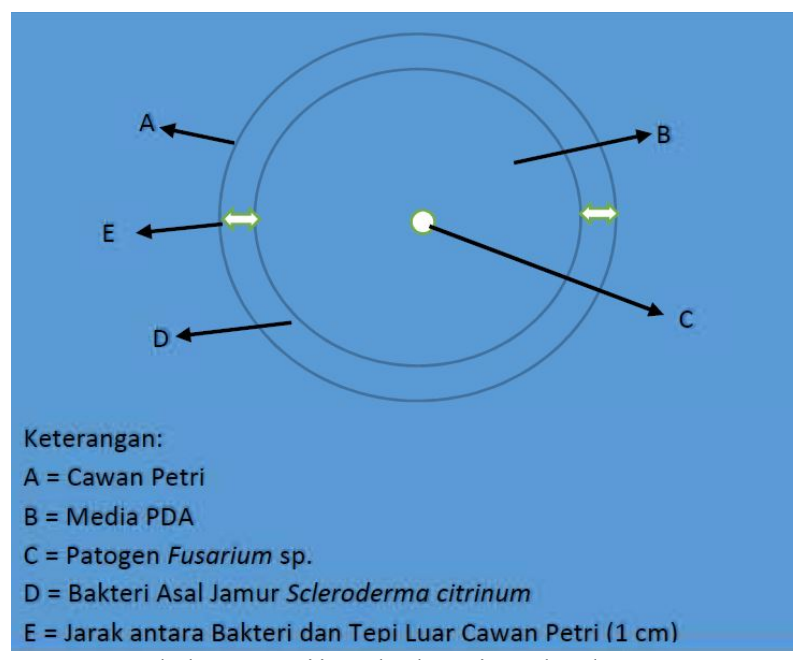

Gambar 4. Model pengujian bakteri terhadap patogen Fusarium sp.

\section{Variabel Pengamatan}

Adapun variabel pengamatan dalam penelitian ini, yaitu:

1. Jumlah bakteri hasil ekstraksi S. citrinum,

2. Penampakan morfologi bakteri asal $S$. citrinum,

3. Pertumbuhan radial miselium cendawan Fusarium sp. yang diuji dengan bakteri asal jamur $S$. citrinum.

Pengamatan dilakukan dengan pengukuran pertumbuhan penyakit tanaman yang diberi perlakuan dengan yang tidak diberi perlakuan (kontrol). Data pengamatan digunakan untuk menghitung perkembangan radial miselium dan persen penghambatan bakteri terhadap penyakit tanaman. Persen penghambatan dihitung dengan menggunakan rumus (May 2011) :

Persen total pertumbuhan fungi

$$
=\frac{\text { Diameter perkembangan fungi }}{\text { Total diameter cawan petri }} \times 100 \%
$$

Persen penghambatan $=100 \%$ - persen total pertumbuhah fungi

\section{Rancanangan Penelitian dan Analisis Data}

Rancangan yang digunakan dalam uji antagonis bakteri asal jamur $S$. citrinum terhadap cendawan Fusarium sp. adalah Rancangan Acak Lengkap (RAL) yang terdiri dari 8 perlakuan dan ulangan sebanyak 3 (tiga) kali, sehingga diperoleh 24 variabel pengamatan. Perlakuan yang di berikan sebagai berikut:

a. Media PDA yang ditanami cendawan patogen Fusarium sp.. (kontrol)

b. Media PDA yang ditanami cendawan patogen Fusarium sp. dan bakteri asal jamur S. citrinum isolat 1 . ( $\mathrm{Scl} 1)$.

c. Media PDA yang ditanami cendawan patogen Fusarium sp. dan bakteri asal jamur S. citrinum isolat 2. ( $\mathrm{Scl} 2)$.

d. Media PDA yang ditanami cendawan patogen Fusarium sp. dan bakteri asal jamur S. citrinum isolat 3. $(\mathrm{Scl} 3)$. 
e. Media PDA yang ditanami cendawan patogen Fusarium sp. dan bakteri asal jamur S. citrinum isolat 4 . ( $\mathrm{Scl} 4)$.

f. Media PDA yang ditanami cendawan patogen Fusarium sp. dan bakteri asal jamur S. citrinum isolat 5. ( $\mathrm{Scl} 5)$.

g. Media PDA yang ditanami cendawan patogen Fusarium sp. dan bakteri asal jamur S. citrinum isolat $6 .(\mathrm{Scl} 6)$.

h. Media PDA yang ditanami cendawan patogen Fusarium sp. dan bakteri asal jamur S. citrinum isolat 7. ( $\mathrm{Scl} 7)$.

Model matematis rancangan acak lengkap (Mattjik 2002 dalam May 2011) sebagai berikut

$\mathrm{Yij}=\mu+\tau \mathrm{i}+\varepsilon \mathrm{ji}$

Yij : Respon penyakit Fusarium sp terhadap perlakuan Bakteri asal Scleroderma citrinum $(1,2,3,4,5,6$, dan 7).

$\mu \quad$ : Nilai tengah pengamatan

$\tau$ i : Perlakuan pemberian bakteri asal $S$. citrinum $(1,2,3,4,5,6$, dan 7).

zji : Tingkat kesalahan akibat perlakuan bakteri asal $S$. citrinum $(1,2,3,4,5,6$, dan 7) dengan ulangan sebanyak 3 kali (i $=1 ; 2 ; 3 ; 4 ; 5 ; 6 ; 7 ; 8)$ dan $(\mathrm{j}=1 ; 2 ; 3)$
Data yang diperoleh selanjutnya diolah menggunakan perangkat statistic SPSS 16. Hasil dari olahan tersebut jika terdapat pengaruh nyata selanjutnya dilakukan uji lanjut Duncan. Hasil penelitian akan ditampilkan dalam bentuk tabel dan gambar.

\section{HASIL DAN PEMBAHASAN}

\section{Jumlah Bakteri Hasil Ekstraksi Scleroderma citrinum}

Hasil ekstraksi sporocarp bakteri dari ektomikoriza (S. citrinum) pada hari ke 3 (tiga) diperoleh bakteri sebanyak 7 jenis bakteri selama 3 hari. Hal ini didukung juga dari hasil penelitian Dahm et al. (2005) dan Varase et al. (1996) dalam May (2011), yang memperoleh bakteri hasil ekstraksi dari jenis ektomikoriza.

\section{Morfologi Bakteri Asal Scleroderma citrinum}

Hasil ekstraksi sporocarp bakteri dari ektomikoriza (S. citrinum) yang terdapat 7 jenis bakteri dapat dideskripsikan berdasarkan morfologi bakteri yang dapat dilihat berdasarkan permukaan, bentuk, warna, dan tepian bakteri. Morfologi bakteri asal $S$. citrinum disajikan pada tabel 1 dan gambar 5 .

Tabel 1. Morfologi bakteri asal S. citrinum

\begin{tabular}{ccccc}
\hline Perlakuan & Bentuk & Tepian & Warna & Permukaan \\
\hline Scl 1 & Circular & Entire & Putih & Flat/Datar \\
Scl 2 & Circular & Serrate & Putih & Flat/Datar \\
Scl 3 & Irreguler & Serrate & Kuning & Flat/Datar \\
Scl 4 & Circular & Lobate & Kuning & Raised/Tebal \\
Scl 5 & Irreguler & Undulate & Kuning & Raised/Tebal \\
Scl 6 & Filamentous & Filamentous & Putih & Flat/Datar \\
Scl 7 & Circular & Lobate & Putih & Convex/Cembung \\
\hline
\end{tabular}




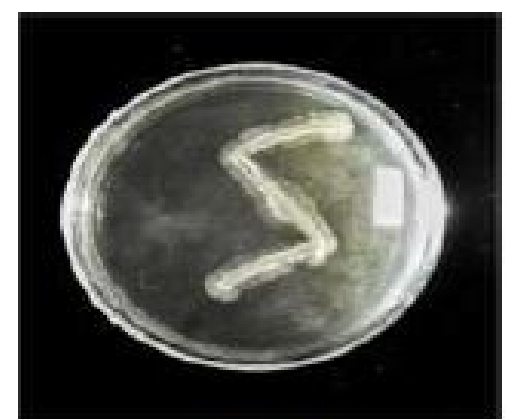

a. $\mathrm{Scl} 1$

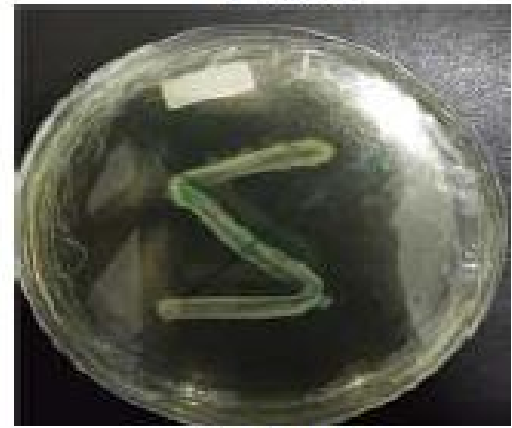

c. $\mathrm{Scl} 3$

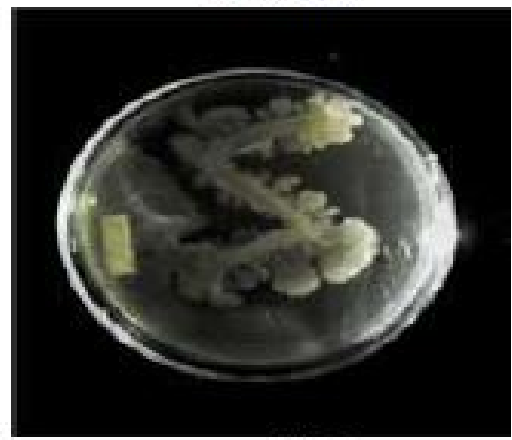

e. $\mathrm{Scl} 5$

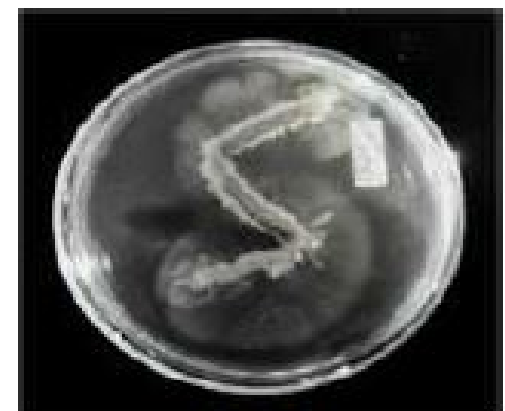

b. $\mathrm{Scl} 2$

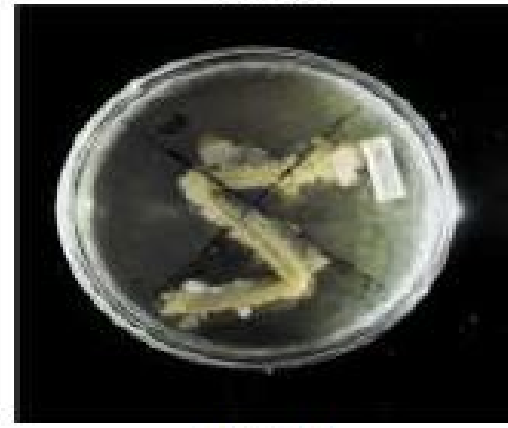

d. $\mathrm{Scl} 4$

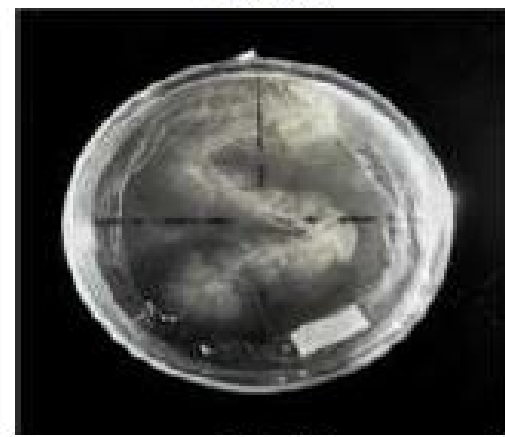

f. $\mathrm{Scl} 6$

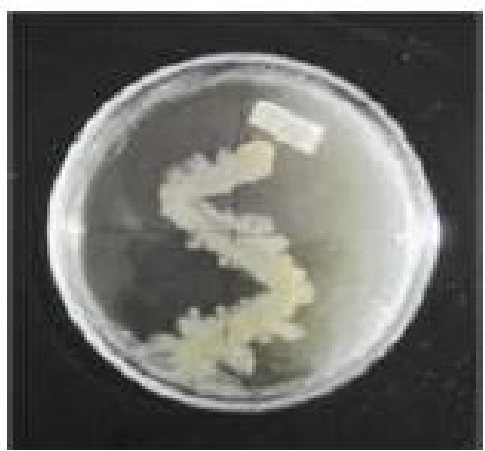

g. Scl 7

Gambar 5. (a-g) Bentuk morfologi bakteri asal S. citrinum 
Uji Antagonis Bakteri Asal S. citrinum

Terhadap Penyakit Tanaman Fusarium

Bakteri asal $S$. citrinum sebanyak 7 jenis bakteri yang telah dideskripsikan tersebut kemudian dilakukan pengujian terhadap cendawan patogen Fusarium sp. Hasil pengujian antagonis penghambatan perkembangan cendawan patogen Fusarium sp. disajikan pada tabel 2 dan secara visual perbedaan penghambatan cendawan patogen dari setiap bakteri antagonis yang diuji tersaji pada gambar 6 .

Tabel 2. Penghambatan perkembangan cendawan patogen Fusarium sp.

\begin{tabular}{ccc}
\hline Perlakuan & $\begin{array}{c}\text { Perkembangan Radial } \\
\text { Miselium }(\mathrm{cm})\end{array}$ & $\begin{array}{c}\text { Persen Penghambatan } \\
(\%)\end{array}$ \\
\hline Kontrol & $9,00 \mathrm{a}^{*}$ & 0,00 \\
Scl 1 & $6,28 \mathrm{bcd}$ & 30,19 \\
Scl 2 & $6,70 \mathrm{~b}$ & 25,56 \\
Scl 3 & $6,55 \mathrm{bc}$ & 27,22 \\
Scl 4 & $6,28 \mathrm{bcd}$ & 30,19 \\
Scl 5 & $6,07 \mathrm{bcd}$ & 32,59 \\
Scl 6 & $5,52 \mathrm{~cd}$ & 38,57 \\
Scl 7 & $5,30 \mathrm{~d}$ & 41,11 \\
\hline
\end{tabular}

*Angka yang diikuti huruf yang sama menunjukkan bahwa pengaruh yang tidak berbeda nyata berdasarkan uji lanjut Duncan pada tingkat kesalahan 5\%.

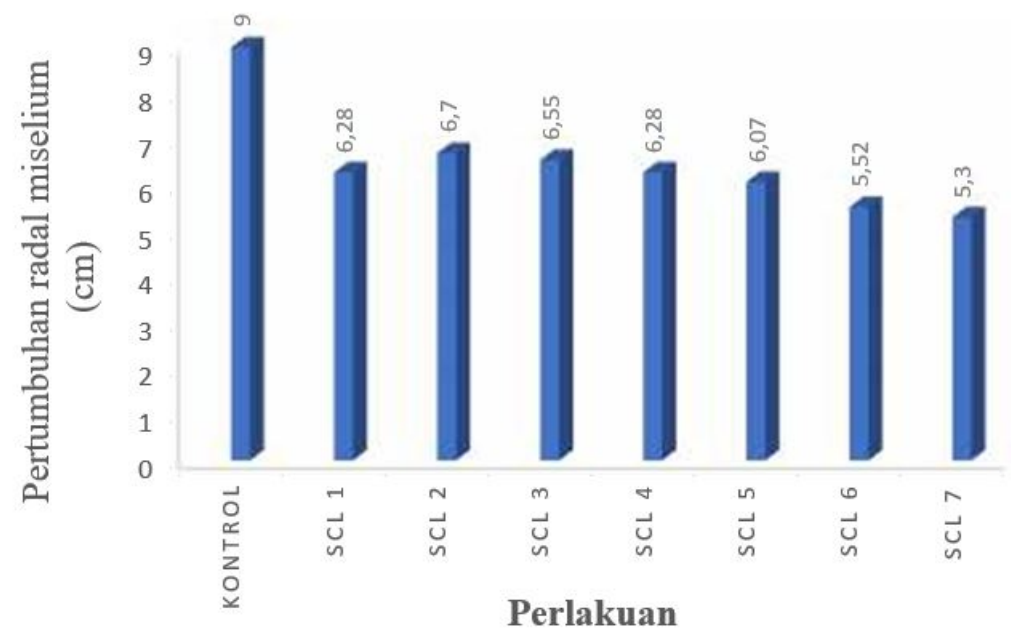

Gambar 6. Grafik perkembangan radial miselium patogen Fusairum sp.

Hasil analisis pengujian statistik dengan uji lanjut Duncan menunjukkan kontrol berbeda nyata terhadap isolat bakteri $\mathrm{Scl} 1, \mathrm{Scl} 2, \mathrm{Scl}$ 3, Scl 4, Scl 5, Scl 6, dan Scl 7. Isolat bakteri Scl 1, Scl 2, Scl 3, Scl 4 dan Scl 5 tidak berbeda nyata, Scl 2 dan Scl 7, sedangkan Scl $1 \mathrm{Scl}$ 4, Scl 5, Scl 6, dan Scl 7 tidak berbeda nyata. Hasil dari setiap perlakuan (kecuali kontrol) mempunyai sifat untuk menghambat pertumbuhan radial cendawan patogen Fusarium sp., tetapi persentase penghambat yang paling tinggi terdapat pada isolat $\mathrm{Scl} 7$ dengan persentase penghambat 41,11\%, lalu diikuti dengan $\mathrm{Scl} 6$, Scl 5, Scl 4, 
Scl 1, Scl 3, dan Scl 2 yaitu masing-masing sebesar 38,57\%, 32,59\%, 30,19\%, 30,19\%, 27,22\%, dan 25,56\%. Hasil dari ekstraksi $S$. citrinum dan uji antagonis dapat disimpulkan bahwa hipotesis penelitian adalah menerima $\mathrm{H}_{1}$, yaitu: ditemukan bakteri dalam sporocarp $S$. citrinum dan memiliki peran sebagai agen antagonis.

Fusarium sp. merupakan spesies patogenik yang menyebabkan penyakit layu pada berbagai tanaman, banyak juga fusarium yang terdapat dalam tanah bertahan sebagai klamidospora atau sebagai hifa pada sisa tanaman dan bahan organik lain (Saragih dan Silalahi 2006).

Penyakit Fusarium sp. diuji dengan bakteri asal $S$. citrinum yang diperoleh berdasarkan hasil pengujian dalam penelitian ini, dimana 7 bakteri asal $S$. citrinum mempunyai kemampuan untuk menghambat penyakit Fusarium sp. yang bervariasi. Isolat bakteri Scl 7 diduga memiliki potensi untuk menghambat patogen Fusarium sp., hal tersebut dapat dilihat dari persentase yang sangat tinggi. Hal ini juga didukung oleh Otter et al. (2004) dalam Hartanto dan Heni (2016) bahwa antagonis dapat di kategorikan memiliki aktivitas penghambatan yang tinggi apabila persentase mencapai $60 \%$ bila persentase hanya mencapai $30 \%$ maka mikroorganisme antagonis tersebut memiliki efek penghambatan yang minimal. Rustam et al. (2011), menyatakan bakteri yang memiliki kemampuan menghambat pada media mengindikasikan isolat tersebut selain memiliki mekanisme penghambatan secara antibiosis, isolat juga memiliki kemampuan penghambatan dalam kompetisi atau persaingan nutrisi atau kompetisi ruang. Hasil penelitian Hutabalian et al. (2015), juga menyatakan bahwa pertumbuhan Fusarium oxysporum dapat dihambat oleh jamur saprofit dan endofit. Penghambatan tersebut diduga terjadi karena adanya persaingan dari kedua isolat, dimana persaingan akan ruang tumbuh dan nutrisi yang berada pada media tumbuh. Hal ini juga didukung Soesanto (2008) dalam Hutabalian et al. (2015) menyatakan persaingan nutrisi dan ruang hidup merupakan suatu peran utama hampir pada semua agen hayati. Salah satu cara untuk pengendalian hayati adalah meningkatkan aplikasi penggunaan fungi ektomikoriza dan fungi mikoriza arbuskula (FMA) dalam pengendalian penyakit hutan (Barea et al. 2005 dalam May 2011).

Menurut Baker (1990) dalam Djatnika (2012), dalam proses antagonistic yang terjadi pada luar tanaman inang (pada media biakan), yaitu dapat bersifat antibiosis, kompetisi, dan eksplotasi (predasi dan hiperparasitisme). Menurut Kamus Besar Bahasa Indonesia (KBBI) Edisi Keempat (2011), bakteri yang bersifat antibiosis ialah bakteri yang menghambat perkembangan suatu populasi akibat pembentukan suatu zat racun yang disebabkan oleh populasi lain. Bakteri yang bersifat kompetisi ialah bakteri yang melakukan persaingan terhadap mikroorganisme lainnya. Bakteri yang bersifat predasi ialah bakteri yang melakukan serangan dan penghancuran langsung terhadap mikroorganisme lain, dan bakteri yang bersifat hiperparasitisme ialah bakteri yang bersifat parasit yang hanya menguntungkan satu organisme tersebut.

Secara visual pada penelitian ini dapat diamati tidak tampak adanya eksploitasi oleh bakteri asal $S$. citrinum sebagai antagonis terhadap penyakit Fusarium sp., sehingga diduga bakteri asal $S$. citrinum memiliki sifat sebagai antibiosis dan kompetisi (pesaing hara). Malinda et al. (2015) juga menyatakan bakteri yang memiliki kemampuan antibiosis diduga mempunyai senyawa yang dapat mengganggu pertumbuhan fisiologis dan morfologis cendawan.

Menurut Sastrosuwignyo (1998); Firdausyi (2005) dalam Wenno (2015), suatu mekanisme penghambatan antagonis bakteri terhadap mikroorganisme lainnya dapat disebabkan oleh adanya suatu aktivitas antibiotik yaitu 
dihasilkannya macam-macam zat antibiotik. Hal tersebut juga disampaikan May (2011) bahwa kemampuan bakteri untuk menghambat perkembangan miselium cendawan patogen kemungkinan ada hubungan aktivitas enzimatik yang dihasilkan oleh bakteri. enzim hidrolitik yang dihasilkan oleh suatu bakteri dapat mendegradasi dinding sel cendawan patogen. Menurut Purwantisari et al. (2005) dalam Malinda et al. (2015), menyatakan ada beberapa cara bakteri untuk menghambat serangan cendawan, diantaranya bakteri memiliki senyawa bioaktif yang mampu mendegradasi dinding sel cendawan, bakteri mampu mengganggu permeabilitas membran sel cendawan, dan bakteri berfungsi sebagai inhibitor terhadap suatu enzim yang dihasilkan cendawan.

\section{DAFTAR PUSTAKA}

Djatnika. 2012. Seleksi bakteri antagonis untuk mengendalikan layu fusarium pada tanaman Phalaenopsis. Balai Penelitian Tanaman Hias. Cianjur. 22(3) : 276-284. http://media.neliti.com/media/publications, (17 Mei 2018).

Hadi S. 2001. Patologi hutan : Perkembangannya di Indonesia. Fakultas Kehutanan. Institut Pertanian Bogor. Bogor.

Hartanto dan Heni. 2016. Uji antagonis 5 isolat Tricoderma dari rizosfer Pinus sp terhadap pertumbuhan cendawan Collectotricum sp. penyebab penyakit antraknosa pada cabai secara in-vitro. Balai Penelitian Tanaman Sayuran.

Hutabalian M, Pinem MI, Oemry S. 2015. Uji antagonis beberapa jamur saprofit dan endofit dari tanaman pisang terhadap
Fusarium oxysporum .sp. cubens di laboratorium. Fakultas Pertanian USU. Medan. 3(2) : 687 - 695. Di unduh pada : http://media.neliti.com/com/media/publicati ons, (24 Mei 2018).

Malinda N, Soekarno BPW, Yuliani TS. 2015. Penghambatan Fusarium oxysporum oleh kultur filtrat bakteri endofit dari tanaman kedelai secara in vitro. IPB. Bogor. 11(6) : 196 - 204. http://journal.ipb.ac.id, (25 Mei 2018).

May NL. 2011. Diversitas bakteri asal spora fungi mikoriza arbuskula Gigaspora sp dan Glomus sp. serta potensinya sebagai mycorrhiza helper bakteria. [Tesis]. Bogor : Program Studi Silvikultur Tropika, IPB.

Rustam, Giyanto, Wiyono S, Santosa DA, Susanto S. 2011. Seleksi dan identifikasi bakteri antagonis sebagai agens pengendali hayati penyakit hawar pelepah Ppadi. Penelitian Pertanian Tanaman Pangan IPB. Bogor. http://panan.litbang.pertanian.go.id (23 Mei 2018).

Saragih YS, Silalahi FH. 2006. Isolasi dan identifikasi spesies fusarium penyebab layu pada tanaman markisa asam. Kebun Percobaan Tanaman Buah Barastagi. Medan. J. Hort. 169(4).

Semangun H. 2001. Pengantar ilmu penyakit tumbuhan. Fakultas Pertanian. Universitas Gadjah Mada. Yogyakarta.

Wenno T. 2015. Pemanfaatan bakteri asal endomikoriza sebagai antagonis cendawan patogen ikutan benih Pometia pinnata, Pterocarpus indicus dan Aquilaria filaria. Fakultas Kehutanan Universitas Papua Manokwari, (Tidak diterbitkan). 